\title{
Mycorrhizae's Role in Plant Nutrition and Protection from Pathogens
}

\author{
Mohammad Imad khrieba* \\ Plant Pathology and Biological Control, National Commission of Biotechnology (NCBT), Syria \\ *Corresponding author: Mohammad Imad khrieba, Plant Pathology and Biological Control, National Commission of Biotechnology \\ (NCBT), Syria
}

\begin{abstract}
Mycorrhizae establish symbiotic relationships with plants and play an essential role in plant growth, disease protection, and overall soil quality. There are two main categories of Mycorrhizae relationships: Endomycorrhizal fungi (Arbuscular Mycorrhizal Fungi) (AMF) form relationships with over $90 \%$ of plants (including turf grasses). Ectomycorrhizae fungi form relationships with only about $2 \%$ of plants, but some of them are quite common. In this scientific review, we will only talk about Endomycorrhizal. Mycorrhizae described in current scientific literature, the Endomycorrhizal the most abundant and widespread. The molecular basis of nutrient exchange between Arbuscular Mycorrhizal (AM) fungi and host plants is presented. The role of AM fungi in disease protection, Root colonisation by Arbuscular Mycorrhizal Fungi (AMF) can improve plant resistance/tolerance to biotic stresses. Although this bio protection has been amply described in different plant systems, the underlying mechanisms remain largely unknown. Besides mechanisms such as improved plant nutrition and competition, experimental evidence supports the involvement of plant defense mechanisms in the observed protection. During mycorrhiza establishment, modulation of plant defenses responses occurs upon recognition of the AMF in order to achieve a functional symbiosis. As a consequence of this modulation, a mild, but effective activation of the plant immune responses may occur, not only locally but also systemically. This activation leads to a primed state of the plant that allows a more efficient activation of defense mechanisms in response to attack by potential enemies.
\end{abstract}

Keywords: Endomycorrhizal; arbuscular mycorrhizal fungi (AMF); Symbiosis; disease protection

\section{Introduction}

Mutually beneficial interactions between plants and microbes are frequent in nature. Common benefits for the plant are improved plant nutrition and/or increased capability to cope with adverse conditions. In the case of Arbuscular Mycorrhizal (AM) associations, the symbioses alter plant physiology, leading to a better mineral nutrition and to increased resistance/tolerance to biotic and abiotic stresses. Although it should be noted that the ability to enhance plant resistance/tolerance differs among AM fungal isolates and can be modulated by environmental conditions, general trends emerge from the multiple studies dealing with mycorrhiza-induced resistance in different path systems. Enhanced resistance/tolerance to soil-borne pathogens has been widely reported in mycorrhizal plants [1]. Arbuscular Mycorrhizal (AM) fungi, which belong to the Glomeromycota order, possess the ability to colonize root cortical cells to build an endosymbiosis relationship with $70-90 \%$ of land plants [2]. The fungi supply mineral nutrients to the host plants in exchange for photosynthesis and provide protection for hosts against pathogens and environmental stress [3]. The formation of arbuscular is the heart of the endosymbiosis Figure 1. However, the molecular mechanisms underlying the ability of the AM fungus to adapt to a broad host range and the formation of these arbuscular have not been elucidated. AM are the most common mycorrhizal type. The name 'arbuscular' is derived from characteristic structures, the arbuscular Figure 1, which occur within the cortical cells of many plant roots and also some mycothalli colonized by AM fungi [4]. This is in part because there was no available AM fungus genome sequence. Recently, the genome sequences of two Rhizophagus irregularis DAOM197198s isolates have been published [5]. The term "mycorrhizosphere" was coined to describe the unique properties of the rhizosphere surrounding and influenced by mycorrhizas [5]. 


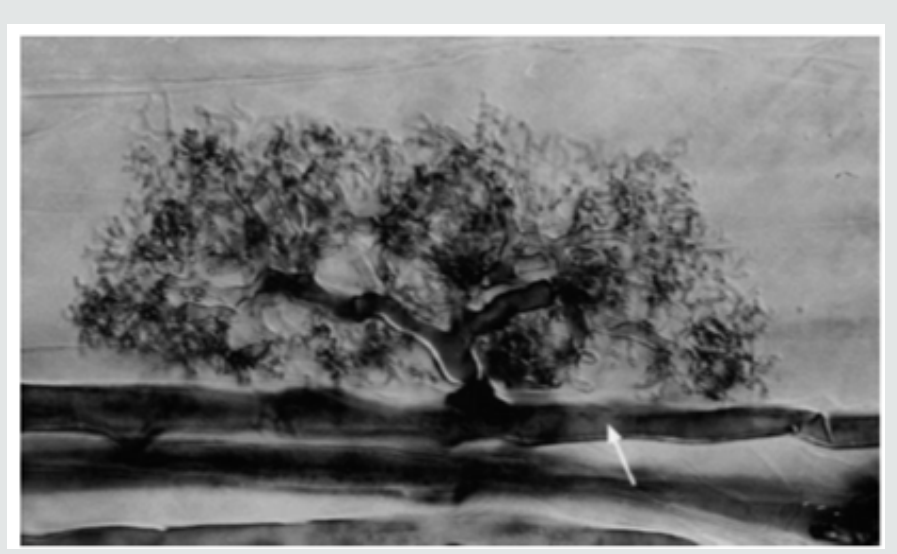

Figure 1: A mature Arum-type arbuscular of Glomus mosseae within a cortical cell of Allium porrum (leek). The arbuscular has grown from a well-developed intercellular hypha, adapted from [4].

Mycorrhizal fungi frequently stimulate plants to reduce root biomass while simultaneously expanding nutrient uptake capacity by extending far beyond root surfaces and proliferating in soil pores that are too small for root hairs to enter. Mycelial networks of mycorrhizal fungi often connect plant root systems over broad areas. These fungi frequently comprise the largest portion of soil microbial biomass [6]. Arbuscular Mycorrhiza (AM) are zygomycetes belonging to the order Glomales. According to both fossil discoveries and DNA sequences, the appearance of both $\mathrm{AM}$ and plants is almost 400 million years old. One of the unique characteristics of $\mathrm{AM}$, when in symbiotic relationship with plant roots, is the significant increase in surface area due to the production of extensive hypha helping plants grow under relatively harsh conditions, such as drought stress and nutrient deficiency conditions. AM are the most common mycorrhizal type [7]. Mycorrhizal symbiosis is one of the most fundamental types of mutualistic plant-microbe interaction. Among the many classes of mycorrhizae, the arbuscular mycorrhizae have the most general symbiotic style and the longest history. However, the genomes of arbuscular mycorrhizal (AM) fungi are not well characterized due to difficulties in cultivation and genetic analysis [8]. This is the first AM fungus genome that has been revealed. The genome sequences can thus provide a way of understanding the molecular mechanisms of how a single AM fungus can intracellular colonize such a wide variety of plant species [5]. This scientific review aims to identify mycorrhizal interactions processes, and potential benefits to plant and the role of Mycorrhizae in plant nutrition, improve growth, and induced the plant to become resistant to soil diseases.

\section{Importance}

AM fungi facilitate uptake of phosphorous as well as nitrogen from the soil into plants. The result of these supplies is improved growth and productivity in host plants [2]. They protect host plants from pathogens and environmental stress. Additionally, AM fungi are beneficial to ecosystem by improving soil quality and carbon cycle. Mycorrhizal fungi form relationships with over 95\% of plant species. They surround and even enter the roots of these plants and provide nutrients such as phosphorus (and even nitrogen) and water to plants in exchange for carbohydrates, usually sugars [9]. In fact, some plants may trade more than $50 \%$ of their carbohydrates with these fungi and other microbes in exchange for the vital role soil microorganisms' play in the soil including:

a. Making nutrients plant ready

b. Producing optimized growing conditions

c. Significantly improve soil characteristics and quality

d. Increasing water availability

In soil that has recently been tilled/worked, compacted, waterlogged, or treated with chemicals, mycorrhizae will be lacking, unfortunately, currently these types of soils are very common. They are not present in imported topsoil or potting soil mix, either, or they cannot be multiplied in compost. In any of these situations, they need to be added back to the soil because they are essential to optimum plant growth and health and should always be used whenever planting or seeding.

\section{Molecular Mechanisms of Mycorrhizal Symbiosis}

AM fungi are obligate biotrophs, solely dependent on the host plants for their survival. The symbiotic mechanism comprises many steps: The first step is the search for the host root, which is an important step in fungal-root-colonization process. The second step is penetration of fungi into the host root for colonization and final establishment of mycorrhizal symbiosis. Some bioactive (These are chemicals released from some specialized cells or tissues to induce functions in nearby cells or tissues of the same or different organism). Molecules like strigolactones secreted by the roots help fungi identify their host plants. Strigolactones also stimulate AM fungal growth and its branching. The fungi recipro cate to this signal by secreting a set of hypothetical factors known as Mycorrhizal Factors (Myc). These factors also play a major role in communication between AM fungi and nitrogen-fixing bacteria. The AM interactions are established further with the induction of seven genes (SYM genes) [10]. 
After spore germination, some fungal-branched hyphae access the root of host and penetrate the cell walls of cortical cells. Ultimately, fungi colonize the root and in the inner root cortical cells a highly branched structure is formed, called an arbuscular, which serves as an interface for nutritional exchange [2]. Endomycorrhizal association of the Vascular-Arbuscular (VA) type, the fungi penetrate the cortical cells of roots and form clusters of finely divided hyphae that ultimately develops into arbuscular [9]. When the host Myc Factor Receptor(s) (MFR) perceive Myc signals, cytosolic calcium secretion is induced in root cells. A second membrane protein (SYMPK) is activated, which codes for a receptor-like kinase with the potential to recognise AM fungal signals directly or indirectly. SYMPK transduce these signals from the cytoplasm to the nucleus by phosphorylating an unknown substrate through its kinase domain [11]. The localization of all downstream elements present in the cytoplasm activates rapid signal transduction (Transmission of chemical sig- plasm, from one cell to another) into the nucleus into the nucleus. Thus, a repeated oscillation of $\mathrm{Ca} 2+$ concentration occurs in the nucleus and cytoplasm, through the alternate activity of $\mathrm{Ca}^{2+}$ channels and transporters. These calcium oscillations are decoded by a Calmodulin-Dependent Protein Kinase (CCaMK). CCaMK phosphorylates the product of one of the SYM genes (CYCLOPS). This eventually leads to the regulation of other genes and finally root colonization [2].

The symbiotic relationship between Arbuscular Mycorrhizal (AM) fungi and the roots of higher plants is widespread in nature. Several ecophysiological studies have demonstrated that AM symbiosis is a key component in helping plants to cope with water stress and in increasing drought resistance by bringing about various changes in the host plant at the morphological level like alterations in root morphology to form a direct pathway of water uptake by extra radical hyphae [12].

\section{Role of mycorrhizae in plant nutrition}

They play important roles in plant resource capture and nutrient cycling. The ability of AM fungi to enhance host plant uptake of relatively immobile nutrients, in particular Phosphorus (P), and several micronutrients, has been the most recognized beneficial effect of mycorrhiza. Arbuscular mycorrhizal fungi absorb inorganic P either from the soluble P pools in the soil, or from insoluble forms, such as, Rock Phosphates (RP) [13, 14]. Recent studies show that mycorrhizal fungus Glomus intraradices solubilized RP through localized alterations of $\mathrm{pH}$ and/or by the production of organic acid anions, that may act as chelating agents. Although, most research regarding the role of mycorrhizae in $\mathrm{P}$ nutrition has dealt with inorganic $\mathrm{P}$, however, few investigations have also considered the utilization of organic P compounds by AM colonized plants. Furthermore, though the mycorrhizal colonization is known to improve plant $\mathrm{N}$ nutrition, yet, their role in making $\mathrm{N}$ available to plants has not been fully recognized. Uptake of other nutrients, such as, $\mathrm{Na}, \mathrm{K}, \mathrm{Mg}, \mathrm{Ca}, \mathrm{B}, \mathrm{Fe}, \mathrm{Mn}, \mathrm{Cu}$, and $\mathrm{Zn}$, by growing plants is influenced by mycorrhizal colonization [15].

\section{Mechanisms of nutrient acquisition by mycorrhizal fungi}

Mycorrhizal fungi are capable of absorbing and transporting almost all the 15 essential macro- and micronutrients vital for growth of the plant. Mycorrhizal fungi ooze out strong chemical compounds into the soil that mobilize firm or rock-bound nutrients such as phosphorous, iron, and other "tightly arrested" mineral nutrients in the soil. The entire process of dissolution and transportation of nutrients is of great importance in providing nutrition to the plant, and this requires the consideration of high levels of fertility by the non-mycorrhizal plants for maintaining their health [16]. Mycorrhizal fungi create an elaborate web of hyphae that confines and absorbs nutrients restoring the nutritional assets in soils. In the non-mycorrhizal situation, much of this fertility is exhausted or mislaid from the soil system. Mycorrhizal interactions may directly influence the growth of the host plant through the improvement in nutritional attainment by the fungal associate or obliquely by altering the transpiration rates and constitution of the rhizospheric micro flora [17]. Mobilization of nutrient from the organic substrates [18], by improving the fertilizer use efficacy [19], or by advantageous alliance with other soil microbes [18]. The two key steps in nutrient absorption from the soil and release of the nutrients through mycorrhizal association involve:

a) Mobilization and acquisition by the fungal mycelia.

b) Transportation of absorbed nutrients across the fungal-root interface.

\section{Mobilization and absorption of nutrients}

In addition to the hyphae that are in the direct touch with the surface of the root, every mycorrhizal fungus also builds up extrametrical mycelium that extends from surface of infected root into the adjacent soil. Both the fungi, Arbuscular Mycorrhizal (AM), manufacture huge quantity of the extrametrical mycelium Among these, arbuscular mycorrhizal mycelium extends up too many centimeters from the surface of the infected root while mycelium most likely spreads up to some meters [20,21]. In both cases, the mycelium stretches adequately afar from the nutrient depletion zone for inaccessible and bound mineral nutrients around each root; moreover, it also exhibits an intricate structure that provides it with an efficient nutrient gathering network [20,22].

\section{Focus on phosphorus nutrition}

Uptake and translocation of phosphate by arbuscular mycorrhizal fungal hyphae and delivery to intraradices interfaces: VA-fungi are known to assist the plants to absorb mineral nutrients from the soil, particularly low available elements like phosphorus. Improvement of $\mathrm{P}$ uptake and plant growth by $\mathrm{AM}$ under conditions of low available phosphorus has been well documented. Improved $\mathrm{P}$ uptake and plant growth were demonstrated in Andisols following AM inoculation of onion, onion and white clover, and kidney bean. Inoculation increased both spore number and the grain weight of kidney bean at a soil-available P level of $10 \mathrm{mg}$ P kg-1, while these 
effects were suppressed when soil-available P was 25 mg P kg-1. Indigenous AM fungi predominate over inoculated species in most soils [23]. The effectiveness of using indigenous AM fungi was investigated in several cropping systems. Soils contained more AM spores following cultivation of mycorrhizal crops (e.g., sunflower, maize, soybean, potato kidney bean, adzuki bean, and wheat) than after cultivation of non-mycorrhizal crops (mustard, radish, sugar beet and buckwheat). As a result, there was increased growth of succeeding crops following mycorrhizal crops. This effect on maize growth and phosphorus uptake was evident in dry soil conditions and was less pronounced with increasing soil moisture [15]. Mycorrhizal fungi in addition to plant roots mediate uptake of $\mathrm{P}$ from soil solution. Though there are different kinds of mycorrhizal fungi, only Arbuscular Mycorrhizal Fungi (AMF) are discussed here. AMF are ubiquitous, occurring in most of the soils. They belong to the phylum Glomeromycota, which has three classes Glomeromycetes, Archaeosporomycetes and Paraglomeromycetes with five orders [Glomerales, Diversisporales Gigasporales, Paraglomerales and Archaeosporales] [24]. The commonly occurring genera of AMF are Glomus, Gigaspora, Scutellospora Acaulospora and Entrophospora. These fungi are obligate symbionts and have not been cultured on nutrient media. AMF are not host specific although evidence is growing that certain endophytes may form preferential association with certain host plants $[25,26]$. They are commonly found in association with agricultural crops, most shrubs, most tropical tree species and some temperate tree species. The fungi being obligate biotrophs do not grow on synthetic media. It is now proved beyond doubt that AMF greatly enhance plant growth. The improved growth is mainly attributed to uptake of diffusion-limited nutrients such as $\mathrm{P}, \mathrm{Zn}, \mathrm{Cu}$, etc. from soil. The other beneficial effects are their role in the biological control of root pathogens, hormone production, greater ability to withstand water stress and synergistic interaction with nitrogen fixers: P solubilizes and plant growth promoting rhizo microorganisms (PGPRs) [25,23].
The role played by these fungi in improving plant growth is much more significant in tropical soils compared to temperate soils. This is mainly because most of the soils of the tropics are of low inherent fertility. They are deficient in phosphorus. In addition to being deficient in phosphorus, they are P fixing, i.e. $75-80 \%$ of the phosphoric fertilizers added get fixed in the soil and is not readily available over the crop period necessitating fresh additions. In acidic soils, they are fixed as iron and aluminum phosphates, while in neutral soils they are fixed as calcium phosphates. Continuous application of $\mathrm{P}$ fertilizers will result in increased concentration of total phosphorus in the soil over times, resulting in large reserves of fixed P. According to Ozanne11, less than $10 \%$ of soil P enters the plant-animal cycle [27]. The improved $P$ nutrition in plants has been explained mainly by the extension of AM fungal hyphae beyond the root system, which allows for the exploration of spatially unavailable nutrients [28]. As mentioned, the most prominent effect of AMF is to improve P nutrition of the host plant in soils with low $P$ levels due to the large surface area of their hyphae and their high affinity $\mathrm{P}$ uptake mechanisms. To substantiate this concept of plant growth promotion by AMF, several studies have shown that AM fungi contribute to up to $90 \%$ of plant P demand [5]. For instance, the $\mathrm{P}$ depletion zone around a non-mycorrhizal roots extends to only 1-2 mm, nearly the length of a root hair whereas extra radical hyphae of AMF extends $8 \mathrm{~cm}$ or more beyond the root making the $\mathrm{P}$ in this greater volume of soil available to the host Figure 2. In mycorrhizal plants, the movement of $\mathrm{P}$ from root to the leaves is also faster. This is attributed to the steepness of $\mathrm{P}$ gradient from the root to the leaves. Conversion of inorganic $\mathrm{P}$ takes place at a faster rate in the shoot system of mycorrhizal plants resulting in less inorganic P in the shoot, thus increasing the steepness of $\mathrm{P}$ gradient from root to the leaves Figure 2. The major organic $\mathrm{P}$ source in the soil is phytate. AMF produce acid phosphatase, which acts on phytate and releases the H2PO4 ions [29].

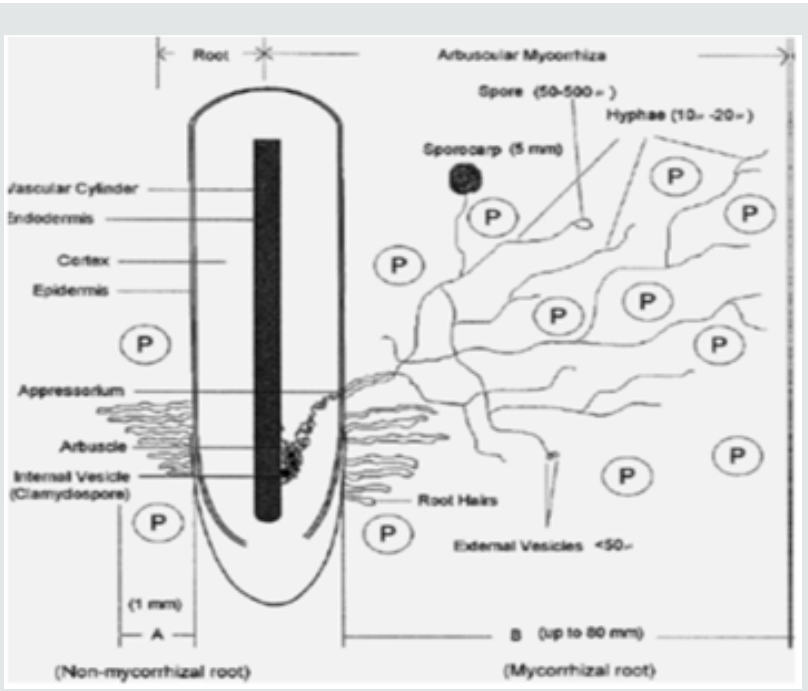

Figure 2: Root colonized by Endomycorrhizal fungus. Note the zone of $\mathrm{P}$ (or other nutrient) absorption by a non-mycorrhizal root (A) and by a mycorrhizal root (B) P phosphate ion, adapted from [74]. 


\section{Plant Growth Hormones}

Mycorrhizal fungi produce plant growth hormones [30]. Arbuscular mycorrhizal (AM) fungi are non-specific symbionts developing mutual and beneficial symbiosis with most terrestrial plants. Because of the obligatory nature of the symbiosis, the presence of the host plant during the onset and proceeding of symbiosis is necessary. However, AM fungal spores being able to germinate in the absence of the host plant [31]. The fungi detect the presence of the host plant through some signal communications. Among the signal molecules, which can affect mycorrhizal symbiosis are plant hormones, which may positively or adversely affect the symbiosis [32]. Different plant hormones can also act as signal molecules and positively or adversely affect mycorrhizal symbiosis. Plant hormones may control the level and hence specificity of mycorrhizal symbiosis. Accordingly, it may be likely to enhance the efficiency of mycorrhizal symbiosis under stress by controlling the level of stress hormones [33,34].

\section{Mycorrhiza in Disease Resistance}

Biological control of plant pathogens presents a compelling method of increasing plant yields by suppressing or destroying pathogens, enhancing the ability of plants to resist pathogens, and/or protecting plants against pathogens. Microorganisms antagonistic to plant pathogens may be derived from the resident microbial community or may be of foreign origin [35]. Although there are concerns towards the release of an organism of foreign extraction, in general, biological control presents a myriad of benefits such as being a component of the environment, resistant to development of chemical pesticide resistance, being relatively safe and risk free, and by being compatible with sustainable agriculture. Arbuscular Mycorrhizal Fungi (AMF) form one such group of organisms that can act as bio protectors of plants [36] (Fitter and Sanders).

\section{Mechanism of disease control by mycorrhizal fungi}

The mycorrhizal symbiosis involves several mechanisms in control of plant diseases:

(i) creating a mechanical barrier for the pathogen penetration and subsequent spread. (Ingham).

(ii) Thickening of cell wall through lignifications and production of other polysaccharides which in turn hinder the entry of root pathogen [37].

(iii) Stimulating the host roots to produce and accumulate sufficient concentrations of metabolities (terpenes, phenols etc.) which impart resistance to the host tissue against pathogen invasion [38].

(iv) Stimulating flavonoid wall infusions as in the case of Laccaria bicolor, which prevented lesion formation by the pathogen Fusarium oxgsporum in roots of Douglas fir [39].

(v) Increasing the concentration of orthodihydroxy phenols in roots, which deter the activity of pathogens [40]. (vi) Producing antifungal and antibacterial antibiotics and toxins that act against pathogenic organisms [41].

(vii) Competing with the pathogens for the uptake of essential nutrients in the rhizosphere and the root surface [42].

(viii) Stimulating the microbial activity and competitions in the root zone (rhizosphere, rhizoplane) and thus preventing the pathogen to get access to the roots [43]. Roots colonized by VAM/AM fungi may also harbour more actinomycetes antagonistic to root pathogens [44].

(ix) Compensating the nutrient absorption system from damage to roots by pathogens [45].

(x) Changing the amount and type of plant root exudates. Pathogens dependent on certain exudates will be at a disadvantage as the exudates change [46].

Resistance to fungal diseases: [47] found that inoculation of onion with Glomus mosseae could significantly reduce pink root disease due to Pyrenochaeta terrestris. Glomus mosseae protected peanut plants from infection by pod rot fungal pathogens Fusarium solani and Rhizoctonia solani [48]. The Glomus intraradices increased P uptake and reduced disease development of Aphanomyces euteiches in pea roots [49] Mycorrhization with Glomus mosseae and G. intraradices induced local or systemic resistance to Phytophthora parasitica in tomato roots [50]. Decreased pathogen development in mycorrhizal and non-mycorrhizal parts of inoculated roots is associated with accumulation of phenolic and plant cell defense response. The protective effects induced by AM fungi against a phytoplasma is reported in tomato [51,52]. Root rot caused by Fusarium solani significantly contributes to crop yield decline up to $50 \%$. The inoculation of common bean (Phaseolus vulgaris) with Glomus mosseae, besides decreasing propagule number of $F$. solani in the rhizosphere, decreased root rot by 34 to $77 \%$ [53]. In the presence of the root modulating symbiotic Rhizobium leguminosarum, mycorrhizal inoculated plants were more tolerant to the fungal root pathogen. This indicates that interactions between mycorrhizal fungi and other rhizosphere microbes might have greater effects on soil-borne pathogens than mycorrhizal fungi alone. [54] found that Glomus fasciculatum reduced Phytophthora root rot of citrus at low level of soil phosphorus but had no effect in high phosphorus soil. The VAM fungi has also been employed as biocontrol agents for Macrophomina root of cowpea and Fusarium wilt of tomato [55]. The understanding of the mechanisms of plant disease resistance in mycorrhizal plants would provide better directions towards the development of efficient crop production and sustainable agriculture. These compositions that contain on mycorrhizae are very important to develop new classes of biocides and contribute to reducing risks to both human health and the environment [56].

Resistance to bacterial diseases: The AMF interact with functionally diverse bacteria such as diazotrophs, biological control agents, and other common rhizosphere inhabitants [57] that often result in significant alterations to plant growth, yield, and nutrition. 
Interactions between mycorrhizal fungi and bacteria may have detrimental (Filion et al.) or beneficial effects (Edwards et al.) or have no effect at all on the plant pathogenic bacterium (Otto and Winkler 1995). Glomus mosseae prevented the infection of soybean plants by $P$. syringae (Shalaby and Hanna), by suppressing the population density of the pathogen in soybean rhizosphere Li et al. also found that $G$. macrocarpum reduced the infection caused by $P$. lacrymans in eggplant and cucumber although no positive growth or yield effect was noted indicating tolerance to the pathogen as a possible mode of action. Inoculation of mulberry with $G$. fasciculatum or G. mosseae in combination with $60-90 \mathrm{~kg}$ of $\mathrm{P}$ per hectare per year reduced the incidence of bacterial blight caused by P. syringae pv. mori (Sharma).

Resistance to viruses diseases: Viruses remain the least studied amongst all the plant disease-causing target organisms listed for mycorrhizae-mediated biocontrol. The general response of mycorrhizal lants to the presence of viral pathogens is as follows:

(a) Mycorrhizal plants apparently enhanced the rate of multiplication of viruses in some plants [57].

(b) More leaf lesions were found on mycorrhizal plants than on non-mycorrhizal plants [58], and

(c) The number of AMF spores in the rhizosphere was reduced considerably [59].

Enhanced viral multiplication and activity in mycorrhizal plants is speculated to be attributed to higher Levels compared to non-mycorrhizal plants. A similar effect was noted in nonmycorrhizal plants fertilized with P [60]. Some workers found that host plants were more susceptible to AMF colonization following infection by a virus. For example, [58] reported that following the inoculation of mycorrhizal and non-mycorrhizal tobacco (Nicotiana glutinosa L.) with Tobacco Mosaic Virus (TMV), mycorrhizal plants exhibited higher levels of AMF colonization. In contrast, mung bean yellow mosaic virus reduced the AMF colonization and yield of mycorrhizal plants [59], while lack of response to viral infection by a mycorrhizal host was demonstrated [61].

\section{Interaction with Other Soil Microbes a Cycle of Benefit}

The interactions between AM fungi and other soil microbes range from positive to negative. There are several mechanisms by which the soil saprophytic microbial community can be affected by AM fungi. Firstly, the AM fungi may affect the quality and quantity of carbon entering the soil food web. As the AM fungus colonizes the plant roots, it improves the plant's nutrient uptake and changes the allocation patterns in plant. Thus, AM colonization is likely to alter the quality and quantity of plant litter [62]. Soil microbes compete with plants for inorganic nutrients [63] and it has been suggested that AM fungal colonization may affect the soil microbial community by increasing the competitive ability of plants against the saprophytic rhizosphere micro flora for common nutrients [64]. On the other hand, there is evidence of possibly mutualistic relationship between
AM fungi and bacteria as the uptake of sparingly soluble $P$ by external AM mycelium may be facilitated by P solubilizing bacteria [65]. These complex direct and plant mediated interactions make it difficult to predict the effect AM fungi on soil microbial community [66]. Between soil microbiota, the mycorrhizal species and plants are establishing extremely complex relations, with positive effects (Azcon-Aguilar and Barea, 1985) or negative effects [66] over the mycorrhization rate and over these processes efficiency. The root exudates are a valuable nutritive resource for rhizosphere microorganisms, qualitative and quantitative properties of these root exudates are influencing those interrelations established between organisms from this level many soil microorganisms can be considered as being neutral, because they do not bring a benefit nor a loss for the plant host or the mycorrhizal species [63]. However, these organisms influence the soil activity and properties, contributing to organic matter mineralization or can be involved in different physic-chemical processes. Although these organisms do not directly interact with the plants, the processes in which they are involved might have influence over the plant development [64]. The rhizosphere bacteria are bacteria already present in the soil and, because of the soil conditions modification (roots development) they find favorable niches to abundantly develop. The rhizospheric microorganisms can have different activities: pathogenic activity, plant protection antibiotics productions etc. [66-70].

\section{Conclusion}

Root colonisation by Arbuscular Mycorrhizal Fungi (AMF) can improve plant resistance/tolerance to biotic stresses [7174]. Although this bioprotection has been amply described in different plant systems, the underlying mechanisms remain largely unknown. Besides mechanisms such as improved plant nutrition and competition, experimental evidence supports the involvement of plant defence mechanisms in the observed protection. During mycorrhiza establishment, modulation of plant defence responses occurs upon recognition of the AMF in order to achieve a functional symbiosis. Because of this modulation, a mild, but effective activation of the plant immune responses may occur, not only locally but also systemically. This activation leads to a primed state of the plant that allows a more efficient activation of defence mechanisms in response to attack by potential enemies. Mycorrhizal fungi protect plant roots from diseases in several ways:

(i) by providing a physical barrier to the invading pathogens. Physical protection is more likely to exclude soil insects and nematode than bacteria or fungi in ectomycorrhizal plants however; some nematodes can penetrate the fungal mantle.

(ii) by competing with the pathogen.

(iii) by producing allopathic chemicals like secondary metabolites, antagonistic chemicals like antibiotics, toxins etc., and amount and type of the root exudates.

For effective and persistent disease management and biocontrol, the need is to evaluate the mycorrhizal symbioses in the natural system under field conditions. The use of mixed inoculum 
of mycorrhizal symbionts can be more effective and give better results than use of a single species. Selection of superior indigenous mycorrhizal symbionts may have an adaptive advantage to the soils and environment in which pathogen and host co-occur as compared to non-indigenous mycorrhizal symbionts. Mycorrhizal fungi not merely assist in uptake of the major plant nutrients such as $\mathrm{P}$ and $\mathrm{N}$ but also help in captivating other micronutrients like $\mathrm{Fe}$, $\mathrm{Cu}, \mathrm{Zn}$, etc. Mycorrhizal fungi implement various means to achieve the task effectively: measuring the greater absorbing surface area of the plants, releasing biochemical compounds along with alliance with other microbes in its ambience. Other than mobilizing the mineral nutrients, mycorrhizal fungi also provide significant $\mathrm{C}$ sink in soil; hence, these have a critical impact on cycling of the elements within soil. Arbuscular mycorrhizas have the ability to alleviate many anthropogenic stresses, including effects of metals and polychlorinated aliphatic and phenolic pollutants. Remediation of soils contaminated with toxic pollutants using specific combinations of plants and species or strains of mycorrhizal fungi deserves increased emphasis. In several studies, evidence was adduced that the benefit of AM was due to improved $\mathrm{P}$ acquisition by the legume, particularly during seedling development. Indeed, $\mathrm{P}$ uptake for each of the three varieties of common bean was highly correlated with the \% root colonization by AM. Positive responses to AM inoculation can occur in unfertilized soil, but are more likely to occur in soils where low available P status has been corrected by superphosphate application. The use of different extract ants for available $\mathrm{P}$ in the studies reviewed did not permit an assessment of the relationship between available P status of soils and response to AM inoculation, but this is one area in which further research is warranted. Similarly, there is presently little or no quantitative data on the role of AM in improving legume symbiotic performance through acquisition of other immobile nutrients or through attenuation of water stress under drought conditions.

\section{References}

1. Whipps JM (2004) Prospects and limitations for mycorrhizas in biocontrol of root pathogens. Can J Bot 82(8): 1198-1227.

2. M Parniske (2008) Arbuscular Mycorrhiza: The Mother of Plant Root Endosymbiosis. Nature Reviews Microbiology 6: 763-775.

3. Sikes BA (2010) When do arbuscular mycorrhizal fungi protect plant roots from pathogens? Plant Signal Behav 5(6): 763-765.

4. Smith SE, Read D (2008) Mycorrhizal symbiosis. Elsevier Academic Press: pp. 815.

5. Lin K, Limpens E, Zhang Z, Ivanov S, Saunders DG, et al. (2014) Single nucleus genome sequencing reveals high similarity among nuclei of an endomycorrhizal fungus. PLoS Genet 10(1): e1004078.

6. Mohammadi K (2011) Soil, plant and microbe interactions. Lambert Academic Publishing pp: 113.

7. Azcon R (1989) Selective interaction between free living rhizosphere bacteria and vesicular arbuscular mycorrhizal fungi. Soil Biology and Biochemistry 21(5): 639-644.

8. Jiang Y, Wang W, Xie Q, Liu N, Liu L, et al. (2017) Plants transfer lipids to sustain colonization by mutualistic mycorrhizal and parasitic fungi. Science 356(6343): 1172-1175.
9. Guitar C, Parniske M (2013) Cell and Developmental Biology of Arbuscular Mycorrhiza Symbiosis. Annual Review of Cell and Developmental Biology 29: 593-617.

10. Bonfante P, Genre A (2010) Mechanism Underlying Beneficial Plant Fungus Interactions in Mycorrhizal Symbiosis. Nature Communications 1(8): 2010.

11.Gutjahr C, Parniske M (2013) Cell and Developmental Biology of Arbuscular Mycorrhiza Symbiosis. Annual Review of Cell and Developmental Biology 29: 593-617.

12. Dar ZM, Masood A, Asif M, Malik MA (2018) Arbuscular Mycorrhizal Fungi: An Approach to Overcome Drought Adversities in Plants. International Journal of Current Microbiology and Applied Sciences $7(3):$ 1040-1049.

13. Smith SE, Smith FA (2011) Roles of arbuscular mycorrhizas in plant nutrition and growth: New paradigms from cellular to ecosystem scales. Annu Rev Plant Biol 62: 227-250.

14.Azcon R, Ambrosano E, Charest C (2003) Nutrient acquisition in mycorrhizal lettuce plants under different phosphorus and nitrogen concentration. Plant Science 165(5): 1137-1145.

15. Bucking H, Liepold E, Ambilwade P (2012) The role of the mycorrhizal symbiosis in nutrient uptake of plants and the regulatory mechanisms underlying these transport processes. In: Dhal NK, Sahu SC (Eds) Plant science.

16. Cabral C, Ravnskov S, Tringovska I, Wollenweber B (2016) Arbuscular mycorrhizal fungi modify nutrient allocation and composition in wheat (Triticum aestivum L.) subjectedto heat stress. Plant Soil 408(1-2): 385399.

17. Marschner H, Dell B (1994) Nutrient uptake in mycorrhizal symbiosis. Plant Soil 159(1): 89-102.

18. Finlay RD (2008) Ecological aspects of mycorrhizal symbiosis: With special emphasis on the functional diversity of interactions involving the extra radial mycelium. J Exp Bot 59(5): 1115-1126.

19. Jeff H, Taylor, Peterson CA (2005) Ectomycorrhizal impacts on nutrient uptake pathways in woody roots. New For 30(2-3): 203-214.

20. Goltapeh EM, Danesh YR, Prasad R, Varma A (2008) Mycorrhizal fungi: What we know and what should we know. In: Varma A (Ed) Mycorrhiza, 3rd Edn. Springer, Heidelberg, pp: 3-28.

21. Oliveira RS, Carvalho P, Marques G, Ferreira L, Nunes M, et al. (2017) Increased protein content of chickpea (Cicer arietinum L.) inoculated with arbuscular mycorrhizal fungi and nitrogen-fixing bacteria under water deficit conditions. J Sci Food Agric 97(13): 4379-4385.

22. Bucking H, Kafle A (2015) Role of arbuscular mycorrhizal fungi in the nitrogen uptake of plants: Current knowledge and research gaps. Agronomy 5(4): 587-612.

23. Effery RP, Simpson RJ, Lambers H, Orchard S, Kidd DR, et al. (2018) Contrasting communities of arbuscule forming root symbionts change external critical phosphorus requirements of some annual pasture legumes. Applied Soil Ecology 126: 88-97.

24. Sturmer SL, (2012) History of the taxonomy and systematics of arbuscular mycorrhizal fungi belonging to the phylum Glomeromycota. Mycorrhiza 22(4): 247-258.

25. Bagyaraj DJ (2011) Microbial Biotechnology for Sustainable Agriculture, Horticulture and Forestry, New India Publishing Agency.

26. Rivera R, Fernandez F, Fernandez K, Ruiz L, Sanchez C, et al. (2007) Advances in the management of arbuscular mycorrhizal symbiosis in tropical ecosystems. In Mycorrhizae in Crop Production (Eds Hamel C and Plenchette C), Haworth Food \& Agricultural Products Press pp. 151196. 
27. Ozanne PG (1980) Phosphate nutrition of plants-A general treatise. In the Role of Phosphorus in Agriculture (eds Kasawneh FE, Sample EC and Kamprath E J), American Society of Agronomy, Crop Science Society America and Soil Science Society America, Madison pp: 559-589.

28. Smith FA, Jacobsen I, Smith SE (2000) Spatial differences in acquisition of soil phosphate between two arbuscular mycorrhizal fungi in symbiosis with Medicago truncatula. New Phytol 147(2): 357-366.

29. Joner EJ, Briones R, Leyval C (2000) Metal binding capacity of arbuscular mycorrhizal mycelium. Plant Soil 226(2): 227-234.

30. Slankis V (1973) Hormonal relationships in mycorrhizal development. In Ectomycorrhizae: Their Ecology and Physiology. Marks, G. C. and Kozlowski. TT (Eds). Academic Press. New York, USA: pp. 151-205.

31. Harrison MJ (2005) Signaling in the arbuscular mycorrhizal symbiosis. Annu Rev Microbiol 59: 19-42.

32. Gryndler M, Hrselova H, Chvatalova I, Jansa J (1998) The effect of selected plant hormones on in vitro proliferation of hyphae of Glomus fistulosum. Biol Plant 41(2): 255-263.

33. Shekoofeh E, Sepideh H, Roya R (2012) Role of mycorrhizal fungi and salicylic acid in salinity tolerance of Ocimum basilicum resistance to salinity. Afric J Biotechnol 11(9): 2223-2235.

34. Duc NH, Mayer Z, Pék Z, Helyes L, Posta K (2017) Combined inoculation of arbuscular mycorrhizal fungi, Pseudomonas fluorescens and Trichoderma spp. for enhancing defense enzymes and yield of three pepper cultivars. Applied ecology and environmental research 15(3): 1815-1829.

35. Ravnskov S, Enkegaard A, Paaske K, Tringovska I, Spliid HN, et al. (2013) Arbuscular myrcorrhiza in an IPM strategy for field-grown vegetables. Poster session presented at Global Root Health Forum, Beijing, China.

36. Zcon Aguilar C, Barea JM (1992) Interactions between mycorrhizal fungi and other rhizosphere microorganisms. In: Allen MF ed. Mycorrhizal Functioning: An Integrative Plant-Fungal Process. New York: Chapman and Hall pp: 163-198.

37. Dehne HW (1982) Interaction between vesicular arbuscular mycorrhizal fungi and plant pathogens. Phytopathology 72(8): 1115-1119.

38. Sampangi RK (1989) Some recent advances in the study of fungal root diseases. Ind Phytopth 22: 1-17.

39. Strobel NE, Sinclair WA (1991) Role of flavonilic wall inclusions in the resistance induced by Laccaria bicolor to Fusarium oxysporum in primary roots of Donglas fir. Phytopathology 81: 420-425.

40. Krishna KR, Bagyaraj DJ (1984) Interaction between Glomus fasciculatum and Sclerotium rolfsii in peanut. Can J Bot 61(9): 2349-2351.

41. Marx DH (1972) Ectomycorrhizae as biological deterents to pathogenic root infections. Ann Rev Phytopath 10: 429-454.

42. Reid CPP (1990) Mycorrhizas. In, The Rhizosphere, J.M. Lynch ed. John Wiley and Sons pp: 281-315.

43. Singh G, Mukerji KG (2006) Root exudates as determinant of rhizospheric microbial diversity. In, Microbial activity in the rhizosphere. KG Mukerji, C Manoharachary, J Singh Eds. Springer Verlag, Berlin, Heidelberg pp. 39-55.

44. Mukerji KG (2002) Rhizosphere Biology. In, Techniques in Mycorrhizal Studies, KG Mukerji, C Manoharachary, BP Chamola Eds. Kluwer Academic Publishers, Dordrecht, The Netherlands pp: 87-101.

45. Smith SE, Reid DJ (1997) Mycorrhizal Symbiosis. Academic Press pp. 605.

46. Matsubara Y, Tamura H, Harada T (1995) Growth enhancement and Verticillium wilt control vesicular-arbuscular mycorrhiza fungus inoculation in eggplant. J Japan Soc Hort Sci 64(3): 555-561.
47. Safir G (1968) The influence of vesicular mycorrhiza on the resistance of onion of Pyrenochaeta terrestris. MS Thesis.

48. Abdalla ME, Abdel Fattah GM (2000) Influence of the Endomycorrhizal fungus Glomus mosseae on the development of peanut pod rot disease in Egypt. Mycorrhiza 10(1): 29-35.

49. Bodker L, Kjoller R, Rosendah S (1998) Effect of phosophate and the arbuscular mycorrhizal fungus Glomus intraradices on disease severity of root rot of peas (Pisum sativum) caused by Aphanomyces euteiches. Mycorrhiza 8(3): 169-174.

50. Pozo MJ, Cordier C, Dumas Gaudot E, Gianinazzi S, Barea JM, et al. (2002) Localized versus systemic effect of arbuscular mycorrhizal fungi on defence responses to Phytophthora infection in tomato plants. J. Exp Bot 53(368): 525-534.

51. Lingua G, D Agostino G, Massa N, Antosiano M, Berta G (2002) Mycorrhiza induced differential response to a yellow's disease in tomato. Mycorrhiza 12(4): 191-198.

52. Lingua G, D Agostino G, Massa N, Antosiano M, Berta G (2002) Mycorrhiza induced differential response to a yellow's disease in tomato. Mycorrhiza 12(4): 191-198

53. Dar GH, Zargar MY, Beigh GM (1997) Biocontrol of Fusarium root rot in the common bean (Phaseolus vulgaris L.) by using symbiotic Glomus mosseae and Rhizobium leguminosarum. Microb Ecol 34(1): 74-80.

54. Davis, RM Menge, JA (1981) Influence of Glomus fasciculatum and soil phosphorus on Phytophthora root rot of citrus. Phytopathology 70(5): 447-452.

55. Ramaraj B, Shanmugam N, Reddy DA (1988) Biocontrol of Macrophomina root rot of cowpea and Fusarium wilt of tomato by using VAM fungi. In: Mycorrhizae for green Asia. A Mahadevan ed. Proc. 1st Asian Conf Mycorrhizae, University of Madras, Madras, India pp. 250-251.

56. Tarraf W, Ruta C, Tagarelli A, De Cillis F, De Mastro G (2017) Influence of arbuscular mycorrhizae on plant growth, essential oil production and phosphorus uptake of Salvia officinalis $L$. Industrial Crops and Products 102: 144-153.

57. Nemec S, Myhre D (1984) Virus Glomus etunicatum interactions in citrus rootstocks [Sour orange, citrus macro phylla, Duncan grapefruit, and potential of mycorrhizal citrus rootstock seedlings to protect against growth suppression by viruses]. Plant Dis 68: 311-314.

58. Schonbeck F and Spengler G (1979). The detection of TMV mycorrhizal cells of the tomato plant by means of immune fluorescence. Phytopathol Z 94: 84-86.

59. Jayaraman J, Kumar D, Jayaraman J, Kumar D (1995) Influence of mungbean yellow mosaic virus on mycorrhizal fungi associated with Vigna radiate var. PS 16. Ind Phytopathology 48: 108-110.

60. Shaul O, Galili S, Volpin H, Ginzberg I, Elad Y, et al. (1999) Mycorrhizainduced changes in disease severity and PR protein expression in tobacco leaves. Mol Plant-MicrobeInteract 12(11): 1000-1007.

61. Takahashi T, Katano H, Yoshikawa N (1994) Evidence forvesiculararbuscular mycorrhizal infection in viroid-infected hop root tissues. Z P flanzenkr P flanzenschutz 101(3): 267-271.

62. Langley JA, Hungate BA (2003) Mycorrhizal controls on belowground litter quality. Ecology 84: 2302-2312.

63. Kaye JP, Hart SC (1997) Competition for nitrogen between plants and soil microorganisms. TREE 12(4): 139-143.

64. Christensen H, Jakobsen I (1993) Reduction of bacterial growth by a vesicular arbuscular mycorrhizal fungus in the rhizosphere of cucumber (Cucumis sativus L.). Biol. Fertil. Soils 15(4): 253-258.

65. Villegas J, Fortin JA (2001) Phosphorus solubilization and pH changes because of the interactions between soil bacteria and arbuscular 
mycorrhizal fungi on a medium containing $\mathrm{NH} 4+$ as nitrogen source. Can. J. Bot 79: 865-870.

66. Larsen J, Cornejo P, Barea JM (2009) Interactions between the arbiscular mycorrhizal fungus Glomus intraradices on the plant growth promoting rhizobacteria Paenibacillus polymyxa and P. macerans in the mycorrhizosphere of Cucumis sativus. Soil Biology \& Biochemistry 41(2): 286-292.

67. Azcon $r$ (1989) Selective interaction between free living rhizosphere bacteria and vesicular arbuscular mycorrhizal fungi. Soil Biology and Biochemistry 21(5): 639-644.

68. Bagyaraj DJ (2011) Microbial Biotechnology for Sustainable Agriculture, Horticulture and Forestry, New India Publishing Agency.

69. Cardon ZG, JL Whitbeck (2007) The rhizosphere. Elsevier Academic Press 235.
70. Dahlgren RA, M Saigusa, FC Ugolini (2004) The nature properties and management of volcanic soils. Adv. Agron 82: 113-182.

71. Dangl J, J Jones (2001) Plant pathogens and integrated defence responses to infection. Nature 411(6839): 826-833.

72. Lin K, Limpens E, Zhang Z, Ivanov S, Saunders DG, et al. (2014) Single nucleus genome sequencing reveals high similarity among nuclei of an endomycorrhizal fungus. PLoS Genet 10(1): e1004078.

73. Lin X, E George, H Marschner (1991) Extension of the phosphorus depletion zone in VA mycorrhizal white clover in a calcareous soil. Plant Soil 136(1): 41-48.

74. Saghir Kahn M, Zaidi A, Musarrat J (2010) Microbes for Legume Improvement (Springer Vienna). 362.

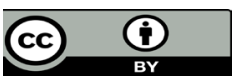

This work is licensed under Creative

Commons Attribution 4.0 License

To Submit Your Article Click Here: Submit Article

DOI: $10.32474 /$ CIACR.2019.08.000277

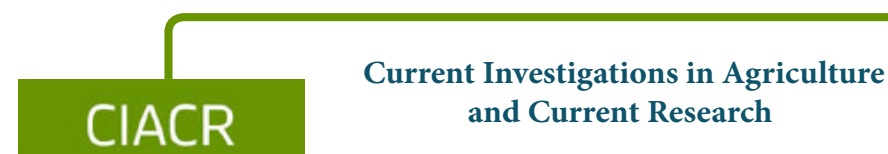

Assets of Publishing with us

- Global archiving of articles

- Immediate, unrestricted online access

- Rigorous Peer Review Process

- Authors Retain Copyrights

- Unique DOI for all articles 